\title{
A Human Rights-Based Approach: Analysis of Administrative Instruments used in the Fight Against COVID 19 in Zimbabwe and Botswana
}

\author{
Feddious Mutenheri \\ Texila American University \\ E-mail:feddious@gmail.com
}

\begin{abstract}
Subsequent to the appearance of the COVID-19 contagion, governments around the world were confronted with the challenge of combating its spread. It has been established that the infection is predominantly human to human and this reality informed the approaches used to counter it. Governments, particularly those perceived to have impeccable democratic credentials, had the difficult decision to deploy martial laws against laissez faire tactics in order to save lives. Most countries resorted to martial law, which gave leaders of governments unfettered state power to make decisions "to save lives". Whereas most Western countries took a wait-and-see approach in implementing State of Emergencies, China and most countries in the developing world were quick to declare them. Developing countries' records on human rights are generally poor. There has been a worldwide human rights confrontation between governments and citizens on the extent of the instruments used to fight COVID 19. Have these instruments been effective? Have they been the only necessary and key instruments to fight the pandemic? To what extent did they impinge on the human rights imperatives of the citizen? This paper interrogates the necessity of using these instruments to combat COVID-19 and their consequences on people's rights. The paper presents the instruments used in Zimbabwe and Botswana and uses the Human Rights-Based Approach (HRBA) to compare their consequences on people's freedoms in these countries. This research uses mixed methods in interrogating the impact of the administrative instruments that were used to combat COVID 19. Where necessary, descriptive and ethnographic approaches are employed to deepen the understanding of the impact of these instruments on human rights.
\end{abstract}

Keywords: Human Rights-Based Approach, State of Emergence, Lockdown, Administrative Instruments, COVID 19 Pandemic.

\section{Introduction}

In the period following the declaration of COVID 19 as a pandemic by the World Health Organisation, countries around the world implemented cocktails of policies to curb its spread. The virus was diagnosed as being transmitted from human to human. The WHO prescribed wearing of masks, social distancing and washing of hands as the primary methods to reduce its spread. No vaccine to date has been found to cure the virus. According to Mutenheri (2020), “...By April 2020, China had the highest figures of recorded infections (81 054), followed by Italy with 53 578, and the USA with 26892 . As of March 22, 2020, the outbreak of the coronavirus disease (COVID-19) had been confirmed in around 188 countries. The virus had infected 308,592 people worldwide, and the number of deaths had totalled 13,069. The most severely affected countries outside of China included Italy, the USA, Spain, and Germany. Zimbabwe and Botswana instituted administrative instruments to curb the spread of the deadly virus. Zimbabwe, using Presidential Powers Act, instituted Statutory Instrument N0. 83, in which a State of Disaster and National Lockdown and prohibition of gatherings were legislated for the 21-day period commencing 30 March 2020; Statutory Instrument 136 of 2020, and other measures which will be discussed below were instituted as well. Botswana's Parliament, on the other hand, promulgated a sixmonth State of Emergency in April which was extended for another six months, solely for the purposes of fighting COVID 19. Besides these political measures, there were attendant economic and social measures that were put in 
place in both these countries that have human rights dimensions to them. It is these measures that this paper seeks to evaluate against the human rights imperative in these two countries.

\section{Definition of words}

\section{Human rights}

According to the OHCHR (1996), these are entitlements or civil liberties that we have simply because we exist as human beings - they are not granted by any state. These universal rights are inherent to us all, regardless of nationality, sex, national or ethnic origin, color, religion, language, or any other status. They range from the most fundamental - the right to life - to those that make life worth living, such as the rights to food, education, work, health, and liberty. (https://www.ohchr.org). Yamin (2008) sums it up by pointing out that "Human rights are conceived as tools that allow people to live lives of dignity, to be free and equal citizens, to exercise meaningful choices, and to pursue their life plans."

\section{Human Rights-Based Approach}

A human rights-based approach (HRBA) is a conceptual framework in which the integration of human rights law and principles should be visible in all work, and in which the aim of all (governmental) programs and activities should be to contribute directly to the realization of one or more human rights.

\section{Statement of the Problem}

There is a rising tide of human rights violations which have been laid bare by the COVID-19 pandemic in Africa. I submit that while the government in Zimbabwe declared various restrictions on people's social, economic and political activities in a bid to upend the deadly contagion, human rights violations of vulnerable groups by law enforcement and public officials have been on the increase in Zimbabwe which has a dire COVID 19 situation, yet Botswana which has implemented similar measures, enjoys a greater level of peace and tranquillity yet also with a relatively effective COVID 19 combat machinery.

\section{Limitations}

The major limitation to this study has been the lockdown of borders which denied me as the researcher, the opportunity to tour Zimbabwe to experience first-hand some of the effects of COVID 19 and to interview some of the respondents. Secondly the research is largely dependent on secondary data and news reports whose veracity sometimes is difficult to verify. Most questionnaires that I sent to my key respondents were not returned on time and others not returned at all. Some of these respondents were key to the understanding of both the Zimbabwe and Botswana human rights situation under COVID 19.

\section{Methods}

This research was to a larger extent a qualitative one depending largely on secondary information as recorded in government reports, newspaper articles and internet databases. I also consulted some key people in informal conversations on their opinions. My observations and recording of events as they happened through the period of the Covid informed some of the perspectives that are contained in this paper.

\section{Discussion}

\section{Theoretical Framework}

Today, more than ever before, State political structures are premised on contractual agreements between the governing class and the governed. Amadasun et al, (2020) argue that social contract theorists have long spoken about commensurate relations among the ruling class and the followers in which the former, via the ballot, determines the outcome of policy-making. From idealism to pragmatism, such contractual principles- under the auspices of a democratic architecture- have now become a normative venture across political dispensations and transitions in many regions of the world, including Africa. (Amadasun, 2020). The COVID-19 pandemic, however has irrevocably shed light on the double standards, hubris, and despotic dispositions of many African leaders. Across the region, there have been widely reported cases of violence against citizens by security forces who were deployed to enforce curfews and lockdowns. (UN, 2020, France 24, 2020).

Outbreaks and health emergencies - such as the new COVID-19 pandemic - pose many ethical and public health questions on how to adequately respond and control transmission. The overall purpose is to keep populations informed and safe. (Schiariti, 2020) In order to do so, 
public health strategies directed at the community level, nationally, or internationally, sometimes require restricting any one individual's rights to freedom of movement and association, for example, using measures such as quarantine in the interest of the greater population. (Leary, 1994). Nevertheless, during epidemics it is crucial to monitor the implementation of public health strategies with conscious attention to human rights, especially of those individuals who are socially, politically and economically vulnerable. (UNGA, 2007). An important point is worth mentioning at the outset, that having rightsbased strategies and tools in place before the events happen is key for an inclusive response.

The equal and inalienable rights of all human beings provide the foundation for freedom, justice and peace in the world, according to the Universal Declaration of Human Rights, adopted by the UN General Assembly in 1948. (UNFPA, 2014). This work is based on the Human RightsBased approach as it would relate to the tackling of the COVID 19 pandemic. This research takes cognisance of the fact that it is usually the poor sections, marginalised groups and politically vulnerable people and groups who are at the receiving end of state's excessive use of power.

It is therefore important to put the COVID 19 consequences into context in order to deploy a relevant human rights-based approach to tackling it. Firstly COVID 19 in many jurisdictions has led to the following: widespread deaths of people (with the poor most people being heavily affected); loss of livelihoods by many families, especially the vulnerable ones; erosion of social justice; loss of political rights particularly in countries run by dictatorial regimes; racial, political and social persecution of the marginalised in societies; lack of access to healthcare; deprivation by the state of the basic needs and, in many cases due to the COVID 19, related corruption.

A human rights-based approach therefore, is about empowering people to know and claim their rights and increasing the ability and accountability of individuals and institutions who are responsible for respecting, protecting and fulfilling these rights. This means giving people greater opportunities to participate in shaping the decisions that impact on their human rights. Any policy meant to tackle the pandemic should engage participatory strategies in order to have a buy in of the very people it seeks to protect. It also means increasing the ability of those with responsibility for fulfilling rights (government and its institutions such as the security services, judiciary and parliament) to recognise and know how to respect those rights, and make sure they can be held to account. A human rights-based approach in this case is about ensuring that both the standards and the principles of human rights are integrated into policymaking as well as the day to day running of the state in wading off the effects of COVID 19.

According to Unicef (2016), there are two main rationales for a human rights-based approach to tackling the pandemic. Firstly, is the intrinsic rationale, acknowledging that a human rights-based approach is the right thing to do, morally or legally; and secondly, the instrumental rationale, recognizing that a human rights-based approach leads to better and more sustainable outcomes. In practice, the reason for pursuing a human rights-based approach is usually a blend of these two. (https://www.unicef.org/)

A human rights-based approach requires the recognition of rights as legally enforceable entitlements and is linked in to national and international human rights law. The State and all other accountable bodies must be sure that their practices and procedures are grounded in human rights law. Under the law they must not breach the human rights of anyone. (Unicef, 2016).

A rights-based response to COVID-19 contains many important aspects, among them, the right to health, equality and nondiscrimination, freedom of peaceful assembly, association and movement, an adequate standard of living, as well as the right to benefit from scientific progress. (UNAIDS, 2020). This viewpoint focuses on the right to health as underpinned by principle of transparency. The right to the highest attainable standard of physical and mental health was first articulated in the Constitution of the World Health Organization. It is enshrined in the International Covenant on Economic, Social and Cultural Rights, the Convention on the Elimination of All Forms of Discrimination against Women, the International Convention on Protection of the Rights of All Migrant Workers and Members of Their Families, the International Convention on the Elimination of Racial Discrimination, and the Convention on the Rights of the Child, among other international and regional treaties; as well 
as in at least 115 national constitutions. (OHCHR, 2008).

The COVID-19 pandemic and the emergency public health measures implemented by governments in response to it have resulted in unprecedented restrictions on the civil liberties of the general population, especially freedom of movement, association and close physical contact with others. This has been used to deny political players other than those in power to be able to carry out their political activities and therefore weakening their voice, and restricting their ability to mobilise. This is particularly important in Africa where there is a dearth of democracy. An important question therefore arises which is: How does the need by governments to curb the transmission of COVID 19 through limiting some of their liberties co-exist with the imperative to respect their universal charter? It is my argument hither that a 'government of the people, by the people, for the people' will at all times derive its mandate from those very people, to implement policies for their good and that a social contract must at all times exist in which there is a balance struck between the state's administrative obligations and the peoples' civil liberties.

\section{Background to Human Rights records in Zimbabwe and Botswana}

In this section it is important to highlight briefly Botswana and Zimbabwe's human rights records from pre-independence through to postindependence. In Zimbabwe, the Liberation struggle has relentlessly been used as a boon to get away with human rights despoliation and sacrilege of democratic precepts. (Mutenheri: 2009). Dating back to 1890 , the period when the British South Africa Company (BSAC) colonised the territory, the liberation struggles have at all material times been violent sadly with impunity. The 1896 Umvukela/Chimurenga in which natives were defeated led to liberation leaders, Kaguvi, Mbuya Nehanda and others being beheaded by the white settlers and yet no justice was ever served on the White perpetrators. This marked a trajectory, in Zimbabwe, of outlandish claim to power without justice for crimes committed in the quest for that power.

During the time, the BSAC and a pioneer column of settlers, expropriated land from the natives in a violent manner. The natives were either taken in as slaves on the newly created white farms or were driven out to dry, rocky and
Tsetse infested areas which were not fit for habitation. These were called reserves. Again, this violent process went on with impunity. It marked the dispossession of the locals' modes of production and set alive the apartheid system in which Whites had special zones, laws and discrete treatment for them while locals had no source of redress.

Fast track to 1966 which officially was the beginning of the Second Chimrenga/Umvukela. Local people took up arms to fight an almost century old oppressive colonial system. It was a very violent war in which a small minority white settler army fought the nationalist guerrilla army. More than four million natives died and by 1980 an elite Lancaster Conference was convened which offered an armistice and gave political independence to Zimbabwe. The underlying feature of this struggle was its violent nature. The new government offered blanket reconciliation to the white settlers with no redress or justice to the traumatised natives.

The Independence government took over a relatively strong economy yet had no significant training in human rights and three years into their rule they were at loggerheads with local political opposition Zimbabwe African People's Union (ZAPU). More than twenty-thousand Ndebele ethnic group were massacred in an ethnicpolitical conflict where the incumbent ethnic group (Zezurus) wanted to consolidate power. Gukurahundi, as it became known was a violent crushing of dissent and to date the perpetrators have not been brought to justice. This alone is the tattered record of the human rights situation in Zimbabwe. The modern-day opposition, The Movement for Democratic Change (MDC) which was formed in 1999 has suffered the same fate to date. At the very time the MDC was formed, Zimbabwe embarked on a controversial Fast Track Land Reform Programme in which the government sought to redress the 1890's land expropriation. The process was so violent and the opposition MDC suffered torture, rape, disappearances and even death as collateral for they were accused of being the front of the colonial Britain against the Land Reform.

Elections in Zimbabwe since 1980 have all been conducted under the stigma of violence. The elections in $(2002 ; 2005 ; 2008 ; 2013 ; 2018)$ all have been characterised by violence with deaths of opposition officials, abductions and disappearances of political opponents reported. 
All this with impunity. A government programme called Operation Murambatsvina in 2005, saw the destruction of urban settlements of people perceived to have supported the opposition in the just ended election. The UN castigated the programme as action against people's fundamental rights.

When the current government came to power in November 2017, they did so via a military coup in which there were reports of widespread deaths. In July of 2018, a disputed election meant to legitimise the coup was characterised by a violent aftermath in which security forces killed more than seven protesters in the CBD of Harare. A Commission of Inquiry set up to investigate these killings pointed to the culpability of the security forces and recommended that perpetrators be prosecuted. To highlight the impunity, two years later, this recommendation had not been implemented.

Botswana, on the other hand, was never directly colonised but, as a result of the upheavals between Shona people living in Bechuanaland and the migrating Ndebele people from the Kalahari Desert into the territory who disturbed their peace and, tensions with Boers in the Transvaal, the then Bechuanaland leaders personally asked for assistance from the British government. While there was direct administration by the British, a system in which tribal rule was established allowed Botswana to peacefully transit from direct protection to establishing a constitutional democratic government by 1966 . Therefore, Botswana never engaged in a violent struggle for its independence.

Botswana's first independence President, Seretse Khama, was a statesman who took over Botswana as one of the poorest countries in Africa to transforming it into a leading economy by his death in 1980 . Though he died in office, the presidency was smoothly passed on to the Vice President Ketumile Masire who was also elected in his own right. Thus, a democratic culture set foot in Botswana. By 1998, Sir Masire retired of his own accord and new elections were held. To date Botswana has had four smooth power transitions which demonstrate the contribution of a non-violent past which predisposed the country to a more democratic and peaceful environment.

The 2018 transition of power from the government of Ian Khama, however, posed a new threat to a history of peaceful transfer of power. In an unprecedented fashion, the outgoing president joined the opposition ranks, threatening to destabilise a tradition in which the current vice president takes over before elections. A report in a local daily, The Standard, reported that, "Khama/Masisi fight threatens Botswana's Stability" and quoted a report which put it bluntly that "...even more respondents to the mark of $83 \%$ "agree" or "strongly agree" that this falling out is likely to affect the political stability of the country."( Sunday Standard, October 20-26, 2019). Even the incumbent president, Dr. Mokgwetsi Masisi, in his 2018 State of the Nation Address admitted that "the transition from the previous administration in 2018 has not been as smooth as expected". (SONA, 5 November 2018). However, the ensuing political and electoral battle did not degenerate into violence but ushered in a robust political contest which, for the first time in the region, saw the incumbent taking on political opponents in a televised electoral debate. This demonstrated the depth of a democratic culture that was founded at the birth of this country.

\section{Analysis of the Instruments applied in Zimbabwe and Botswana to Fight COVID 19}

In this section I show how a culture of democracy and respect for human rights (or lack thereof) have found expression in the ways in which the two countries of Botswana and Zimbabwe have handled, and continue to handle, the COVID 19 pandemic. I submit that this crisis has exposed on one hand, the penchant by tyrannical leaders to use state power to suppress people's human rights and on the other hand, how an environment with functional state institutions and a political will for respect of human rights can sustain a peaceful and democratic environment in which human rights are respected. The two examples used here are an example of how the South-South cooperation debate in entrenching human rights and African solutions to African problems intonation can be advanced with a view to learning and deriving from success stories in the region and learning lessons from failed examples like Zimbabwe.

Following the declaration by the World Health Organisation of COVID-19 as a global pandemic, a state of disaster was declared in Zimbabwe on the 20th of March 2020. A "National Lockdown and prohibition of gatherings" was legislated for 
the 21-day period commencing 30 March 2020. The extent of lockdown has been reviewed and revised since then with the latest change taking effect from 22 July 2020 with a 18.00 to 06.00 curfew being implemented and business operations for non-essential services, low risk sports and permitted gatherings being restricted to times between 09.00 and 15.00. (https://home.kpmg). Many other measures such as direct and indirect Tax measures, employmentrelated measures (state compensation schemes and training), Economic stimulus measures (loans and moratorium on debt repayments) were also put in place to cushion citizens against adverse effects of the national lockdown. The Zimbabwe government has published 17 statutory instruments since March 2020 regulating the management of COVID-19, including national lockdown rules aimed at slowing down the spread of the respiratory disease. (https://zimfact.org).

President Emmerson Mnangagwa's announcement of a 21-day national lockdown across Zimbabwe to combat the spread of the Covid-19 virus was accompanied by a raft of laws, which have been described as draconian, excessive and as unconstitutional. Statutory Instrument (SI) 83 of 2020, the Public Health (Covid-19 Prevention, Containment and Treatment) (National Lockdown) Order, 2020, set out restrictions that potentially violated fundamental rights to property and to freedom of expression. (https://www.theindependent.co.zw).

Perchance, the most sweeping provision in curtailing freedom of expression was the provision in SI 83 of 2020 to punish the publication or communication of false or fake news during the national lockdown period. This offense attracts an excessive punishment of 20 years imprisonment. Section 14 of the regulations says: "For the avoidance of doubt, any person who publishes or communicates false news about any public officer, official or enforcement officer involved with enforcing or implementing the national lockdown in his or her capacity as such, or about any private individual that has the effect of prejudicing the state's enforcement of the national lockdown, shall be liable for prosecution under Section 31 of the Criminal Law Code ("Publishing or communicating false statements prejudicial to the state") and liable to the penalty there provided, that is to say a fine up to or exceeding level 14 or imprisonment for a period not exceeding 20 years or both." (https://allafrica.com/stories/202004030617.html ) .

According to Dewah Mavhinga, a Human Rights activist, while it is essential that journalists and members of the public take care not to spread false news, this provision potentially violates the constitution's Section 61 guarantee of the right to freedom of expression in that it is too broad and vague, and provides for excessive punitive measures. If implemented as currently framed, this law will constrain the work of journalists, unduly muzzle social media, and prevent legitimate criticism of the authorities' response to Covid-19. (https://www.theindependent.co.zw).

This type of offence appears to be less about protecting public health than safeguarding the State against scrutiny of its management of the COVID-19 pandemic, with a very harsh sentence as deterrent. It has a chilling effect on freedom of expression and public accountability by the State. In an unusual turn, the offence (section 31(a)(iii) of the Criminal Code) has been declared unconstitutional by the Constitutional Court of Zimbabwe in the case of Chimakure \& Others $\mathrm{v}$ Attorney General. The Court held that the offence was overbroad, that the penalty was disproportionate, and that the offence had a chilling effect on the exercise of freedom of expression. (Gonese et al, 2020).

Probably the most dramatic example of the attempts by the government in Zimbabwe to act on such draconian laws was an internationally publicised case of an award-winning journalist, Hopewell Chin' ono. For publishing and exposing corrupt government activities the journalist went through a histrionic persecution by the state in which for forty-five days he was refused bail (itself a right under Zimbabwean laws). Dr. Alex Magaisa, (August, 2020) a Constitutional expert summed up this case:

The Chin'ono case has a higher profile. Chin'ono is an award-winning journalist, with associations at top institutions of learning, such as Harvard. It is meant to send a strong authoritarian message to all social media users. The aim is to intimidate and force citizens into submission. It is designed to get people to police themselves on social media. This includes censoring not only what others say on social media but also what they say. It represents a massive curtailing of free speech. The regime knows it has little power over social media, but 
jailing a few prominent users will serve as an example to others. (Magaisa, 8, August 2020).

Acting under the cover of the State of Disaster and the National Lockdown rules, the Zimbabwe government banned all political activities in the country. However, while political activities from the ruling ZANU (PF) party could go on, (cases in point are the political party primary elections in Kwekwe in August) those organised by opposition political parties were banned or dealt with violently by security forces - a case in point is the $31^{\text {st }}$ July 2020 organised protests whose organisers were incarcerated to thwart the protests and a dozen others who were arrested after participating in the actual protest.

During the subsistence of the lockdown it became clear, government was using lawfare. According to Magaisa (18, August 2020), "in warfare, combatants rely on guns and ammunition. They trade fire. The ones with supreme technology and organisational skills usually win. There is a different kind of war that takes place without guns and ammunition. In this war, the law is the primary weapon. This kind of war has been referred to as lawfare." The Supreme Court of Zimbabwe handed down a potently destabilising judgement to the main opposition Movement for Democratic Change (MDC) in the SC 56-20 - MDC et al v Mashavira et al - Supreme Court judgment of 31st March 2020. In essence, the admittedly moot judgement sought to turn back the wheels of time by resurrecting a political party of 2014 that had died with the death of its founding leader, Morgan Tsvangirai. This judgement has been used to date to dismantle the popular opposition party's hold in the parliament, replacing its deputies with political proxies of the ruling party. Using lawfare, the ZANU PF government used its politically captured institutions (security services and the judiciary) to weaken the political opposition.

Abductions and torture of political opponents were reported during the lockdown to fight COVID. Two cases made international highlights. Firstly, was the reported abduction, torture, sexual abuse and arrest of three girls, officials in the opposition MDC Alliance party. They were accused of having marched in protest over the hunger induced by the lockdown. Their case at the time of writing was still being postponed. The second case was that of a young journalist named Tawanda Muchehiwa, who movie-style, was caught on CCTV cameras being abducted by state agents. The abductions have similar traits, linked to a choreographed statestyle political persecution. These and many other cases expose the worries among human rights activists in Zimbabwe who have always highlighted the heavy-handed tactics used by the Zimbabwe government particularly now under COVID restrictions. Amadasun (2020) contends that "suffice to underscore that such rights violations are not a matter of an isolated case since deaths and injuries resulting directly from these excessive uses of force have been reported in many African countries including Nigeria, Zimbabwe, Kenya, and South Africa."

To highlight how the administrative measures were used in Zimbabwe the Health Minister declared a ban on all elections during lockdown. Zimbabwe's electoral commission had just announced that by-elections to fill at least thirtyfive parliamentary and eighty-four local government vacant seats would be held on December 5, 2020. The ban announced by Vice President Constantino Chiwenga, who also doubles up as Health and Child Care minister, coincided with a mass recall of opposition legislators under controversial circumstances. Alex Magaisa said the ban was evidence that President Emmerson Mnangagwa was using the Covid-19 to stifle democracy. "Statutory Instrument 225A effectively banning byelections in Zimbabwe is living proof of it. President Mnangagwa is lifting restrictions in other areas, but not in elections, but the legality of this statutory instrument is doubtful. It seeks to amend not only the Electoral Act but also the constitution. The Health minister does not have power to do that. Second, the statutory instrument cannot operate retrospectively as it seeks to do. It's all very clumsy." (Magaisa, 2020). According to David Coltart, "the ban effectively suspends section 158 sub-section 3 of the constitution of Zimbabwe, which stipulates the time within which by-elections need to be conducted and a statutory instrument has no power to suspend a constitution,". (https://allafrica.com).

The role of security services in the enforcement of lockdown and its regulations captured the human rights debate in Zimbabwe. Section 213(2) of the Constitution states:

"With the authority of the President, the Defence Forces may be deployed in Zimbabwe ... in support of the Police Service and other 
civilian authorities in the event of an emergency or disaster."

It is important to note that no matter if the President had authorised it, soldiers have no power to arrest civilians as they would have done if the authorisation were given in terms of section 18 of the Maintenance of Peace and Order Act. Reports grew of the police force and the military using gruelling and humiliating punishments to enforce quarantine on the poorest and most vulnerable groups, including those who live hand-to-mouth and who risk starving if they do not defy lockdowns to seek work and food. In addition to an increase in police brutality during lockdown, Transparency International pointed out that there was an increase in bribery and corruption, which thrived during this time of crisis, when institutions and oversight mechanisms are weak and public trust is low. (Gonese, et al, 2020). Enforcement officers must respect the fundamental human rights of people they encounter in the course of their duties. In particular they must respect people's right to life, to human dignity and their right not to be subjected to cruel or degrading treatment.

In early April 2020, Botswana declared a sixmonth state of emergency due to COVID-19 and passed the Emergency Powers COVID-19 Regulations. Botswana initially declared a public health emergency in terms of its Public Health Act before withdrawing the declaration and declaring a state of emergency instead. Soon after the declaration, reports emerged of people being assaulted by the police for allegedly breaching lockdown regulations. (Gonese, et al, 2020). From a democratic discourse, it is instructive that the government immediately issued a statement on 11 April 2020, condemning the assault of citizens and calling on law enforcement agencies to uphold the rule of law and respect for human rights. This prompt response marked a crucial moment showing political will to respect human rights during COVID 19. The Botswana government demonstrated that excesses of law enforcement agencies would not be tolerated giving credence to the argument that the institutional framework in the country is independent and can be checked and balanced.

There was spirited debate on the need by government to declare a State of Emergency as opposed to a Public Health Emergency. The fundamental binary of the debate was primarily between a suspicious opposition camp and an extremely cautious state. To that end, besides political posturing by the opposition there hasn't been evidence of threatening violation of human rights in Botswana. Political will was given at the highest level of government when the president assured the nation that, the State of Emergency was intended to deal only with the COVID-19 crisis and would not in any way undermine people's fundamental rights. According to Motsamai (2020), Botswana's fight against COVID-19 pandemic was in line with the country's human rights-based approach to development. A human rights lawyer Tshiamo Rantao corroborated the human rights situation in Botswana arguing that human rights violations have not been cause for concern during the first State of Public Emergency (SOE) effective for a period of six months pointing out that a lot of lockdown conflicts or cases which could be noticed were Labour matters between workers and their employers due to deferment or salary slices. (https://allafrica.com).

A raft of economic, employment and tax measures that the government put in place helped to cushion Botswana from the devastating effects of COVID 19. According to the Botswana Trade and Investment Centre, Botswana's economic response to the COVID-19 has been ranked in the top 10 responders to COVID-19 economic challenges ranking 2nd after Egypt. (https://www.gobotswana.com).

\section{Conclusion}

From the foregoing it is clear that the two neighbours, Zimbabwe and Botswana have completely different human rights infrastructures and these set ups instructed the way COVID 19 administrative instruments were used. On one hand Zimbabwe authorities, due to the chequered human rights past, manipulated these instruments to asphyxiate people's basic rights, to strangle opposition political space and to inhibit scrutiny of its management of the COVID-19 pandemic. On the other hand, administrative instruments used in Botswana were rooted in a long history of democratic practice and a human rights-based approach to development. Covid actually helped to strengthen that culture because despite the fear of the State of Emergency being used to deal with political opponents, it had patently been used as a legal instrument for the purposes of fighting the pandemic and protecting the people of Botswana from the possible disaster it could cause. Leaders 
with a dictatorial leaning find opportunities to curtail people's rights, even in crisis, to entrench their power - the case in Zimbabwe - yet, democratic leaning leaders take even the most difficult and unpopular decisions to save their people even if it threatens their power-the case in Botswana.

\section{References}

[1] Amadasun S., Omorogiuwa T.B.E. (2019). Applying anti-oppressive approach to social work practice in Africa: Reflections of Nigerian BSW students. Journal of Humanities and Applied Social Sciences.

https://www.emerald.com/insight/content/doi/10.110 8/JHASS-12-2019-082/full/html [Google Scholar].

[2] David Coltart, quoted in an article by Moses Matenga titled: Zimbabwe: Chiwenga Ban Stirs Confusion retrieved from https://allafrica.com/stories/202010040024.html.

[3] France24 (2020). Security forces use violent tactics to enforce Africa's coronavirus shutdowns.

Retrieved from:

https://www.france24.com/en/20200401-security-

forces-use-violent-tactics-to-enforce-africa-scoronavirus-shutdowns.

[4] GoneseT et al, (2020) A Legal Overview of The Impact of Covid-19 On Justice and Rights in Southern Africa, SALC Policy Brief, No. 1 of 2020.

https://allafrica.com

[5] Joint United Nations Programme on HIV and AIDS (UNAIDS), Rights in the time of COVID-19: Lessons from HIV for an effective, community-led response (Geneva: UNAIDS 2020). Available at https://www.unaids.org/sites/default/files/media_asse t/human-rights-and-covid-19_en.pdf .

[6] Leary VA. The right to health in international human rights law. Health Hum Rights 1994; 1: 24-56.

[7] Magaisa, A, T, retrieved from, Zimbabwe bans by-elections citing Covid-19, https://nation.africa/

[8] Magaisa, A. T, Big Saturday Read: Lawfare: The removal of Beatrice Mtetwa, 18 August 2020. https://www.bigsr.co.uk

[9] Magaisa, A. T, Big Saturday Read: Zimbabwe - a case of political persecution, 8, August 2020. https://www.bigsr.co.uk
[10] Motsamai, M, (2020). Botswana Uses Human Rights Approach in Covid-19 Fight, https://allafrica.com

[11] Mutenheri, F \& Kokorwe, K, L. (2020) Globalization or De-linking? Gauging the Efficacy of Global Administration to Global Pandemics in the Face of the Novel Corona Virus Between December 2019 and the First Quarter of 2020, Texila International Journal of Academic Research, Volume 7 , Issue 1.

[12] Office of the High Commissioner for Human Rights and the World Health Organization, The Right to Health (Geneva: OHCHR 2008). Available at: https://www.ohchr.org/Documents/Publications/Facts heet31.pdf

[13] Schiariti, V., (2020) The human rights of children with disabilities during health emergencies: the challenge of COVID-19, Mac Keith Press.

[14] State of The Nation Address by His Excellency Dr. Mokgweetsi E.K. Masisi, President of The Republic of Botswana to The First Meeting of the Fifth Session of The Eleventh Parliament, $5^{\text {th }}$ November 2018, Gaborone.

[15] The Sunday Standard, (2019). Khama/Masisi fight threatens Botswana's stability.

[16] UN (2020). UN raises alarm about police brutality in COVID-19 lockdowns. Retrieved from: https://Aljazeera.com/amp/news/2020/04/raisesalarm-police- brutality-covid-19-lockdowns200428070216771.html.

[17]UN General Assembly, (2007). Convention on the Rights of Persons with Disabilities: Resolution / Adopted by the General Assembly, 24 January 2007, A/RES/61/106.

https://www.refworld.org/docid/45f973632.html. [18]UNFPA, (2014) The Human Rights-Based Approach, https://www.unfpa.org/human-rightsbased-approach

[19] UNICEF, (2016) Human Rights-based Approach to Programming, https://www.unicef.org

[20] Yamin, A.E, (2008). "Will we take suffering seriously? Reflections on what applying a human rights framework to health means and why we should care," Health and Human Rights 10, no. 1. 